Vica J. E. Saija, Wewenang Pemerintah Daerah Dalam

Jurnal Sasi Vol.20 No.1 Bulan Januari-Juli 2014

\title{
WEWENANG PEMERINTAH DAERAH DALAM PEMBERIAN IZIN LINGKUNGAN HIDUP
}

\author{
Oleh: Vica J. E. Saija
}

\begin{abstract}
The results showed that local governments have the authority to give a license for environmental management based on the Chapter 237 Law Number 32 of 2004 Concerning the Local Government Jo Chapter 63 Law Number 32 of 2009 on Environmental Protection and Management, verse (2) letter $r$ and verse (3) letter $o$. As a holder of the delegation, the local government then have the authority to issue permits and enforce the law on consent in the form of monitoring and enforcing sanctions. Licensing authority for environmental management by local governments in its implementation was not maximized yet, this is due to the Law Number 32 of 2009 on Environmental Protection and Management, which does not have implementing regulations, the rule of umbrella act is to set the basic terms only, that contributes to there was no concrete licensing division of the authorized government, both at the central and regional. Therefore, it is the authority of government including local government (Ministers, Governors, Regents/Mayors) should be based on the criteria of externality, accountability, and efficiency. And recommended that the licensing authority for environment management, in its implementation, should be based on the principle of Good Licensing Governance on Based Natural Resources, in order to prevent abuse of authority and to simplify the licensing process. The Law Number 32 of 2009 it is implementation, it still needs to be followed up with any implementing regulation in order to run as it is expected.
\end{abstract}

Keyword: Authority, Government, Environmental License

\section{A. PENDAHULUAN.}

Pengelolaan lingkungan hidupdalam sistem hukum Indonesia telah diatur dalamUndang-Undang Nomor 32 Tahun 2009 Tentang Perlindungan Dan Pengelolaan Lingkungan Hidup - Lembaran Negara Republik Indonesia Tahun 2009 Nomor 140 - Tambahan Lembaran Negara Republik Indonesia Nomor 5059. (Selanjutnya disingkat UUPPLH). Menurut Undang-Undang ini, lingkungan hidup adalah kesatuan ruang dengan semua benda, daya, keadaan, dan makhluk hidup, termasuk manusia dan perilakunya, yang memengaruhi alam itu sendiri.

Pasal 3 UUPPLH, menegaskan bahwa perlindungan dan pengelolaan lingkungan hidup bertujuan untuk melindungi wilayah Negara Kesatuan Republik Indonesia dari pencemaran dan/atau kerusakan lingkungan hidup; menjamin keselamatan, kesehatan, dan kehidupan manusia; menjamin kelangsungan kehidupan makhluk hidup dan kelestarian ekosistem; menjaga kelestarian fungsi lingkungan hidup; mencapai keserasian, keselarasan, dan keseimbangan lingkungan hidup; menjamin terpenuhinya keadilan generasi masa kini dan generasi masa depan; menjamin pemenuhan dan perlindungan hak atas lingkungan hidup sebagai bagian dari hak asasi manusia; mengendalikan pemanfaatan sumber daya alam secara bijaksana; mewujudkan pembangunan berkelanjutan; dan mengantisipasi isu lingkungan global. 
Tujuan dari perlindungan dan pengelolaan lingkungan hidup seperti yang terurai diatas, hendak mengamanatkan pentingnya perlindungan dan pengelolaan lingkungan hidup yang penting fungsinya baik untuk kesejahteraan maupun kelangsungan hidup semua makhluk hidup saat ini maupun yang akan datang, apalagi untuk saat ini kerusakan lingkungan secara global terlihat mengkhawatirkan, bahkan negara kita pun termasuk mengalami masalah tersebut.

Dalam pengelolaan lingkungan hidup terdapat hubungan antara lingkungan hidup dengan beberapa bidang lainnya seperti perindustrian, kehutanan, pertambangan dan lain-lain. Konsekuensi dari hubungan bidang-bidang tersebut terletak pada izin usaha dari tiap-tiap bidang yang harus mengantongi izin lingkungan, hal ini sesuai dengan amanat Pasal 36 ayat (1) UUPLH yaitu "setiap usaha dan/atau kegiatan yang wajib memiliki amdal atau UKL-UPL wajib memiliki izin lingkungan". Itu berarti bahwa Undang-Undang Nomor 32 Tahun 2009 menjadi payung hukum atau umbrella act atau kaderwet bagi peraturan perundang-undangan lainnya.

Peranan lingkungan hidup sebagai aset bangsa dan negara sangat penting sehingga diperlukan suatu pendekatan yang bijak dalam pengelolaanya.Pendekatan yang bijak terhadap pengelolaan lingkungan hidup ini, berkaitan pula karena lingkungan hidup sangat bersentuhan langsung dengan aktivitas pembangunan.Oleh karena begitu pentingnya lingkungan hidup, maka setiap rencana dan/atau kegiatan yang dapat menimbulkan dampak besar dan penting terhadap lingkungan hidup, wajib memiliki analisis mengenai dampak lingkungan hidup. (Supriadi : 2006 : 191).

Pengelolaan lingkungan hidup merupakan tanggung jawab dan kewajiban bersama antara masyarakat, pemerintah dan dunia usaha. Dengan demikian pengelolaan lingkungan hidup merupakan hak atau peran yang meliputi peran dalam proses pengambilan keputusan baik dengan cara mengajukan keberatan maupun dengan pendapat atau dengan cara lain yang ditentukan dalam proses penilaian analisis mengenai dampak lingkungan hidup atau perumusan kebijakan lingkungan hidup.

Dalam pelaksanaan lebih lanjut menyebutkan bahwa "sumber daya alam dikuasai oleh negara dan dipergunakan untuk sebesar-besarnya bagi kemakmuran rakyat, serta pengaturannya ditentukan oleh pemerintah". Untuk melaksanakan ketentuan itu maka pemerintah :

1. Mengatur dan mengembangkan kebijaksanaan dalam rangka pengelolaan lingkungan hidup.

2. Mengatur penyediaan, peruntukan, penggunaan, pengelolaan lingkungan hidup dan pemanfaatan kembali sumbar daya alam termasuk sumber daya genetika.

3. Mengatur pembuatan hukum dan hubungan hukum antara orang atau subyek hukum lainya serta perbuatan hukum terhadap sumber daya alam dan sumber daya buatan, termasuk sumber daya genetika.

4. Mengendalikan kegiatan yang mempunyai dampak sosial

5. Mengembangkan pendanaan bagi upaya pelestarian fungsi lingkungan hidup sesuai peraturan perundang-undangan yang berlaku. Hal yang menyangkut pengaturan, pembinaan, pengembangan industri adalah kewenangan pemerintah. Dalam hal kewenangan campur tangan pemerintah dalam pergaulan sosial ekonomi masyarakat, dikenal adanya kebijaksanaan publik (Public Policy).

Dalam pelaksanaan kegiatan pemerintahan, yang dilakukan seperti dengan memberikan pelayanan publik kepada masyarakat (public service).Salah satu bentuk pelayanan publik untuk masyarakat adalah pemberian izin yang hanya dapat diperoleh dari pemerintahan sebagai penyelengara pemerintahan negara untuk menjalankan usaha dilingkungan masyarakat. Bentuk kebijaksanaan pemerintah secara konkrit yaitu dalam 
Vica J. E. Saija, Wewenang Pemerintah Daerah Dalam.

bentuk izin. Pemberian izin tersebut dimaksudkan untuk mengendalikan masyarakat dalam hubungannya dengan berbagai aspek kehidupan masyarakat, misalnya izin pembuangan limbah cair ke dalam air, diberikan dengan syarat-syarat tertentu guna mengendalikan pencemaran air, karena suatu kegiatan industri dapat menimbulkan dampak terhadap lingkungan (pencemaran).

Konsekuensi dari penyelenggaraan pengelolaan dan pemanfaatan sumber daya alam berkaitan dengan wewenang perizinan yang diatur dalam perundang-undangan menyangkut pengelolaan dan pemanfaatan sumber daya alam, baik yang terkait dengan UUPPLH maupun dalam Undang-Undang 32 Tahun 2004 tentang Pemerintahan Daerah - Lembaran Negara Republik Indonesia Tahun 2004 Nomor 125 Tambahan Lembaran Negara Republik Indonesia Nomor 4437. (Selanjutnya disingkat Undang-Undang Nomor 32 Tahun 2004).

Mengacu dari pemikiran bahwa pemerintah daerah memiliki kewenangan dalam pemanfaatan sumber daya alam dan sumber daya lainnya, itu berarti bahwa pemerintah daerah memiliki kewenangan untuk mengeluarkan izin bagi setiap kegiatan dalam wilayah daerahnya.Namun dalam implementasinya, wewenang perizinan dalam bidang tertentu tidak diberikan sepenuhnya kepada daerah.Hal ini pun ditemukan dalam Undang-Undang nomor 32 tahun 2009 tentang Perlindungan dan Pengelolaan Lingkungan Hidup, oleh karena dalam hal perizinan ternyata masih ada sebagian urusan yang menjadi kewenangan dari Menteri. Berdasarkan uraian tersebut diatas, maka masalah yang diangkat dalam penulisan ini adalah bagaimana implementasi wewenang pemberian izinpengelolaan lingkungan hidup oleh pemerintah daerah?

\section{B. PEMBAHASAN}

Undang-Undang Nomor 32 Tahun 2009 merupakan perubahan terhadap UndangUndang Nomor 23 Tahun 1997 tentang Pengelolaan Lingkungan Hidup. Pengaturan antara Undang-Undang Nomor 32 Tahun 2009 dengan Undang-Undang Nomor 23 Tahun 1997 memiliki perbedaan, secara filosofi Undang-undang ini memandang dan menghargai bahwa arti penting akan hak-hak asasi berupa hak atas lingkungan hidup yang baik dan sehat bagi warga negara. Undang-Undang Nomor 32 Tahun 2009, juga memasukkan landasan filosofi tentang konsep pembangunan berkelanjutan dan berwawasan lingkungan dalam rangka pembangunan ekonomi. Ini penting dalam pembangunan ekonomi nasional karena persoalan lingkungan kedepan semakin kompleks dan sarat dengan kepentingan investasi. Karenannya persoalan lingkungan adalah persoalan kita semua, baik pemerintah, dunia investasi maupun masyarakat pada umumnya.

Perbedaan yang dapat dijumpai, terutama dengan kaitannya terhadap adanya penguatan pada Undang-Undang Nomor 32 Tahun 2009 tentang prinsip-prinsip perlindungan dan pengelolaan Lingkungan Hidup yang didasarkan pada tata kelola pemerintahan yang baik karena dalam setiap proses perumusan dan penerapan instrumen pencegahan pencemaran dan/atau kerusakan lingkungan hidup serta penanggulangan dan penegakan hukum mewajibkan pengintegrasian aspek transparansi, partisipasi, akuntabilitas dan keadilan.

Undang-undang 32 tahun 2009, memberikan kewenangan yang luas kepada pemerintah dalam hal ini Menteri untuk melaksanakan seluruh kewenangan pemerintahan dibidang perlindungan dan pengelolaan lingkungan hidup serta koordinasi dengan instansi lain. Hal ini tidak ditemukan pada Undang-Undang Nomor 23 Tahun 1997, sehingga apabila kita cermati unsur pemerintahan daerah disini termasuk meliputi kekayaan alam yang dimiliki dan 
berada pada suatu daerah tertentu di Indonesia.

Selain itu pula, terkait dengan masalah otonomi daerah, undang-undang ini juga memberikan kewenangan yang sangat luas kepada pemerintah daerah dalam melakukan perlindungan dan pengelolaan lingkungan hidup di daerah masing-masing. Seperti yang dijelaskan dalam bagian penjelasan Undang-Undang Nomor 32 tahun 2009 pada point 8 bagian Pertama, dikatakan bahwa Undang-Undang ini juga mengatur :

1. Keutuhan unsur-unsur pengelolaan lingkungan hidup;

2. Kejelasan kewenangan antara pusat dan daerah;

3. Penguatan pada upaya pengendalian lingkungan hidup;

4. Penguatan instrumen pencegahan pencemaran dan/atau kerusakan lingkungan hidup,yang meliputi instrumen kajian lingkungan hidup strategis, tata ruang, baku mutu lingkungan hidup, kriteria baku kerusakan lingkungan hidup, amdal, upaya pengelolaan lingkungan hidup dan upaya pemantauan lingkungan hidup, perizinan, instrumen ekonomi lingkungan hidup, peraturan perundang-undangan berbasis lingkungan hidup, analisis resiko lingkungan hidup, dan instrumen lain yang sesuai dengan perkembangan ilmu pengetahuan dan teknologi;

5. Pendayagunaan perizinan sebagai instrumen pengendalian;

6. Pendayagunaan pendekatan ekosistem;

7. Kepastian dalam merespons dan mengantisipasi perkembangan lingkungan global;

8. Penguatan demokrasi lingkungan melalui akses informasi, akses partisipasi, dan akses keadilan serta penguatan hak-hak masyarakat dalam perlindungan dan pengelolaan lingkungan hidup;

9. Penegakan hukum perdata, administrasi, dan pidana secara lebih jelas;
10. Penguatan kelembagaan perlindungan dan pengelolaan lingkungan hidup yang lebih efektif dan responsif; dan

11. Penguatan kewenangan pejabat pengawas lingkungan hidup dan penyidik pegawai negeri sipil lingkungan hidup.

Aspek hukum administrasi dalam Udang-Undang Nomor 32 Tahun 2009 dilakukan bersama-sama dengan aspek hukum perdata dan aspek hukum pidana agar dikembangkan satu sistem hukum perlindungan dan pengelolaan lingkungan hidup yang jelas, tegas dan menyeluruh guna menjamin kepastian hukum sebagai landasan bagi perlindungan dan pengelolaan sumberdaya alam serta kegiatan pembangunan lain. Bentuk penguatan tersebut diatas dapat dilihat antara lain dari aspek pidana, perluasan alat bukti yang ada, dan pengembangan asas Ultimum Remedium yakni mewajibkan penerapan penegakan hukum pidana sebagai upaya terakhir setelah penegakan hukum administrasi dianggap tidak berhasil. Yang mana penerapan asas ini, hanya berlaku bagi tindak pidana formil tertentu, yaitu pemidanaan terhadap pelanggaran baku mutu air limbah,emisi,dan gangguan.

Penerapan asas hukum pada Undang-Undang Nomor 32 Tahun 2009 juga tetap mengedepankan bentuk-bentuk Alternative Dispute Resolution (ADR) melalui jalur diluar pengadilan seperti mediasi dan arbitrasi. Jalur pengadilan juga dapat dibedakan lagi menjadi penerapan hukum pidana ataupun penerapan hukum perdata. Penerapan hukum perdata dilakukan melalui ganti kerugian dan pemulihan lingkungan, tanggung jawab mutlak, hak gugat pemerintah dan pemerintah daerah, hak gugat masyarakat dan hak gugat organisasi lingkungan.

Upaya perlindungan dan pengelolaan lingkungan hidup menjadi kewajiban bagi negara, pemerintah, dan seluruh pemangku kepentingan dalam pelaksanaan pembangunan berkelanjutan agar lingkungan hidup Indonesia dapat tetap menjadi sumber dan 
penunjang hidup bagi rakyat Indonesia serta makhluk hidup lain.

Ketentuan Pasal 1 angka (3) UUPPLH, menetapkan bahwa pembangunan berkelanjutan sebgai upaya sadar dan terencana yang memadukan aspek lingkungan hidup, sosial, dan ekonomi ke dalam strategi pembangunan untuk menjamin keutuhan lingkungan hidup serta keselamatan, kemampuan, kesejahteraan, dan mutu hidup generasi masa kini dan generasi masa depan.

Dalam pengelolaan lingkungan hidup, pengaturan mengenai perizinan sesuai dengan UUPPLH merupakan perangkat hukum yang bersifat preventif. Upaya preventif dalam rangka pengendalian dampak lingkungan hidup perlu dilaksanakan dengan mendayagunakan secara maksimal instrumen pengawasan dan perizinan. Dalam hal pencemaran dan kerusakan lingkungan hidup sudah terjadi, perlu dilakukan upaya represif berupa penegakan hukum yang efektif, konsekuen, dan konsisten terhadap pencemaran dan kerusakan lingkungan hidup yang sudah terjadi. Sehingga perlu dikembangkan satu sistem hukum perlindungan dan pengelolaan lingkungan hidup yang jelas, tegas, dan menyeluruh guna menjamin kepastian hukum sebagai landasan bagi perlindungan dan pengelolaan sumber daya alam serta kegiatan pembangunan lain.

Tidaklah mudah memberikan definisi apa yang dimaksud dengan izin, hal ini disebabkan karena antara pakar tidak terdapat persesuaian paham, masing-masing melihat dari sisi yang berlainan terhadap objek yang didefinisikannya. Didalam Kamus Hukum, izin (vergunning) dijelaskan sebagai izin dari pemerintah berdasarkan undang-undang atau peraturan perundang-undangan atau peraturan pemerintah yang disyaratkan untuk perbuatan yang pada umumnya memerlukan pengawasan khusus, tetapi yang pada umumnya tidak dianggap sebagai hal-hal yang sama sekali tidak dikehendaki (Ridwan HR : 2006 : 208).
Sebenarnya dasar pemberian izin untuk perorangan atau badan hukum swasta adalah timbul strategi dan teknik yang dipergunakan oleh pemerintah untuk menguasai atau mengendalikan berbagai keadaan, yakni dengan melarang tanpa izin tertulis untuk melakukan kegiatan-kegiatan apapun yang hendak diatur atau dikendalikan oleh pemerintah (Prajudi Atmosudirjo : 1994 : 96). Dengan perkataan lain melalui sistem perizinan tersebut pihak penguasa melakukan campur tangan kedalam atau atas proses jalannya kegiatan-kegiatan masyarakat tertentu.

Menurut Bagir Manan izin dalam arti luas berarti suatu persetujuan dari penguasa berdasarkan peraturan perundang-undangan untuk memperbolehkan melakukan tindakan atau perbuatan tertentu yang secara umum dilarang (Ridwan HR : 2006 : 207-208). Sehubungan dengan pendapat Bagir Manan N. M. Spelt dan J. B. J. M. ten Berge disunting oleh Philipus M Hadjon membagi pengertian izin dalam arti luas dan sempit yaitu sebagai berikut :

- Dalam arti luas

Izin adalah salah satu instrumen yang paling banyak digunakan dalam hukum administrasi.Pemerintah menggunakan izin sebagai sarana yuridis untuk mengemudikan tingkah laku para warga.

Izin ialah suatu persetujuan dari penguasa berdasarkan undang-undang atau peraturan pemerintah untuk dalam keadaan tertentu menyimpang dari ketentuan-ketentuan larangan perundangan.

- Dalam arti sempit

Izin adalah pengikatan-pengikatan pada suatu peraturan izin pada umumnya didasarkan pada keinginan pembuat undang-undang untuk menghalangi keadaan-keadaan yang buruk. Tujuannya ialah mengatur tindakan-tindakan yang oleh pembuat undang-undang tidak seluruhnya dianggap tercela, namun dimana ia menginginkan dapat melakukan pengawasan sekedarnya. 
Izin merupakan instrumen yuridis dalam bentuk ketetapan yang bersifat konstitutif dan yang digunakan oleh pemerintah untuk menghadapi atau menetapkan peristiwa konkret. Izin bersifat konstitutif yakni ketetapan yang menimbulkan hak baru yang sebelumnya tidak dimiliki oleh seseorang yang namanya tercantum dalam ketetapan itu. Sebagai ketetapan, izin itu dibuat dengan ketentuan dan persyaratan yang berlaku pada ketetapan pada umumnya.

Dalam melaksanakan dan menegakkan ketentuan hukum positif diperlukan wewenang, tanpa wewenang tidak dapat dibuat keputusan yuridis yang bersifat konkret (harus ada wewenang atau asas legalitas), oleh karena itu izin harus berdasarkan wewenang yang diberikan oleh peraturan perundang-undangan. Menurut Marcus Lukman, kewenangan pemerintah dalam bidang izin itu bersifat diskresionare power atau berupa kewenangan bebas, dalam arti kepada pemerintah diberi kewenangan untuk mempertimbangkan atas dasar inisiatif sendiri hal-hal yang berkaitan dengan izin, misalnya pertimbangan tentang :

1. Kondisi-kondisi apa yang memungkinkan suatu izin dapat diberikan kepada pemohon;

2. Bagaimana mempertimbangkan kondisi-kondisi tersebut;

3. Konsekuensi yuridis yang mungkin timbul akibat pemberian izin atau penolakan izin dikaitkan dengan pembatasan peraturan perundang-undangan yang berlaku;

4. Prosedur apa yang harus diikuti atau dipersiapkan pada saat dan sesudah keputusan diberikan baik penerimaan maupun penolakan pemberian izin.

Beragam organ pemerintahan baik di tingkat pusat maupun tingkat daerah, mulai dari administrasi Negara tertinggi (presiden) sampai dengan administrasi Negara terendah (lurah), berwenang memberikan izin. Itu berarti bahwa izin hanya boleh dikeluarkan oleh organ pemerintahan.
Instrumen pencegahan pencemaran dan/atau kerusakan lingkungan hidup berdasarkan Pasal 14 UUPPLH terdiri atas:

a. KLHS;

b. Tata Ruang;

c. Baku Mutu Lingkungan Hidup;

d. Kriteria Baku Kerusakan Lingkungan Hidup;

e. Amdal;

f. UKL-UPL;

g. Perizinan;

h. Instrumen Ekonomi Lingkungan Hidup;

i. Peraturan Perundang-undangan Berbasis Lingkungan Hidup;

j. Anggaran Berbasis Lingkungan Hidup;

k. Analisis Risiko Lingkungan Hidup;

1. Audit Lingkungan Hidup; dan

m. Instrumen Lain Sesuai Dengan Kebutuhan dan/atau Perkembangan Ilmu Pengetahuan.

Berdasarkan Pasal 1 Angka 35 Undang-Undang 32 Tahun 2009 maka pengertian izin lingkungan adalah izin yang diberikan kepada setiap orang yang melakukan usaha dan/atau kegiatan yang wajib amdal atau UKL-UPL dalam rangka perlindungan dan pengelolaan lingkungan hidup sebagai prasyarat untuk memperoleh izin usaha dan/atau kegiatan. Hal ini berarti izin lingkungan harus dimiliki tidak hanya untuk kegiatan usaha yang berdampak pada lingkungan hidup sehingga harus memiliki dokumen amdal (analisis dampak lingkungan) tetapi juga pada kegiatan usaha yang tidak berdampak penting terhadap lingkungan hidup harus memiliki dokumen UKL-UPL (upaya pengelolaan lingkungan hidup dan upaya pemantauan lingkungan hidup) yang diperlukan bagi proses pengambilan keputusan tentang penyelenggaraan usaha dan /atau kegiatan.

Dapat disimpulkan bahwa izin lingkungan tidak dapat diberikan tanpa ke tiga dokumen tersebut, yakni analisis mengenai dampak lingkungan (Amdal), upaya pengelolaan lingkungan hidup (UKL) dan upaya pemantauan lingkungan hidup (UPL), itu berarti setiap usaha dan/atau 
kegiatan yang berhubungan dengan ke tiga dokumen tersebut merupakan usaha dan/atau kegiatan yang izinnya dinaungi dibawah izin lingkungan karena izin lingkungan merupakan prasyarat untuk memperoleh izin usaha dan/atau kegiatan.

Izin lingkungan memberikan kepastian hukum kepada pengusaha bahwa sejak awal mereka telah memenuhi semua ketentuan di bidang lingkungan hidup. Pengusaha harus mendapat izin lingkungan sebelum memperoleh izin usaha, oleh karena izin lingkungan itu bertujuan sebagai:

a. Instrument dalam pengendalian pemanfaatan sumber daya alam;

b. Instrument dalam pengendalian pencemaran dan/atau kerusakan lingkungan hidup; dan

c. Instrument dalam memberikan kepastian hukum bagi pelaksanaan usaha dan/atau kegiatan.

Lebih lanjut tentang izin lingkungan, ditetapkanlah Peraturan Pemerintah Republik Indonesia Nomor 27 Tahun 2012 Tentang Izin Lingkungan - Lembaran Negara Republik Indonesia Tahun 2012 Nomor 48. (Selanjutnya disebut PP Nomor 27 Tahun 2012). PP ini merupakan peraturan pelaksana dari UUPPLH. Menurut PP Nomor 27 Tahun 2012 Pasal 1 angka 1, izin lingkungan adalah izin yang diberikan kepada setiap orang yang melakukan usaha dan/atau kegiatan yang wajib Amdal atau UKL-UPL dalam rangka perlindungan dan pengelolaan lingkungan hidup sebagai prasyarat memperoleh izin usaha dan/atau kegiatan. Untuk permohonan izin lingkungan diatur dalam Pasal 42 ayat (1) yaituPermohonan Izin Lingkungan diajuka n secara tertulis oleh penanggungjawab Usaha dan/atau Kegiatan selaku Pemrakarsa kepada Menteri, Gubernur, atau Bupati/Walikota sesuai dengan kewenangannya. Selanjutnya untuk penerbitan izin lingkungan terdapat dalam Pasal 47 ayat (1) Izin Lingkungan diterbitkan oleh:

a. Menteri, untuk Keputusan Kelayakan Lingkungan Hidup atau Rekomendasi UKL-UPL yang diterbitkan oleh Menteri; b. Gubernur, untuk Keputusan Kelayakan Lingkungan Hidup atau Rekomendasi UKL-UPL yang diterbitkan oleh Gubernur; dan

c. Bupati/Walikota, untuk Keputusan Kelayakan Lingkungan Hidup atau Rekomendasi UKL-UPL yang diterbitkan oleh Bupati/Walikota.

Berbicara tentang kewenangan yang dimiliki oleh pemerintah daerah dalam menerbitkan izin, maka tidaklah dapat dipisahkan dari peraturan mengenai Pemerintahan Daerah. Terkait dengan tugas dan wewenang Pemerintah dan Pemerintah Daerah dalam UUPPLH, telah diatur di dalam Pasal 63 diamanatkan bahwa Pemerintah memiliki tugas dan wewenang untuk menerbitkan izin lingkungan, Pemerintah Provinsi juga menerbitkan izin lingkungan pada tingkat Provinsi dan pemerintah Kabupaten/Kota menerbitkan izin pada tingkat Kabupaten/Kota. Untuk pasal ini, tidak ada penjelasan lebih lanjut. (Lihat Undang-Undang Nomor 32 Tahun 2009).

Aspek hukum administrasi dalam Udang-Undang Nomor 32 Tahun 2009 dilakukan bersama-sama dengan aspek hukum perdata dan aspek hukum pidana agar dikembangkan satu sistem hukum perlindungan dan pengelolaan lingkungan hidup yang jelas, tegas dan menyeluruh guna menjamin kepastian hukum sebagai landasan bagi perlindungan dan pengelolaan sumberdaya alam serta kegiatan pembangunan lain. Bentuk penguatan tersebut diatas dapat dilihat antara lain dari aspek pidana, perluasan alat bukti yang ada, dan pengembangan asas Ultimum Remedium yakni mewajibkan penerapan penegakan hukum pidana sebagai upaya terakhir setelah penegakan hukum administrasi dianggap tidak berhasil. Yang mana penerapan asas ini, hanya berlaku bagi tindak pidana formil tertentu, yaitu pemidanaan terhadap pelanggaran baku mutu air limbah,emisi,dan gangguan.

Penerapan asas hukum pada Undang-Undang Nomor 32 Tahun 2009 juga 
tetap mengedepankan bentuk-bentuk Alternative Dispute Resolution (ADR) melalui jalur diluar pengadilan seperti mediasi dan arbitrasi. Jalur pengadilan juga dapat dibedakan lagi menjadi penerapan hukum pidana ataupun penerapan hukum perdata. Penerapan hukum perdata dilakukan melalui ganti kerugian dan pemulihan lingkungan, tanggung jawab mutlak, hak gugat pemerintah dan pemerintah daerah, hak gugat masyarakat dan hak gugat organisasi lingkungan.

Berbicara tentang desentralisasi, maka diketahui bahwa desentralisasi di Negara Kesatuan berarti adanya penyerahan kekuasaan dari pemerintah pusat sebagai badan publik nasional kepada pemerintah daerah sebagai badan publik lokal.

Dalam menyelenggarakan urusan pemerintahan yang menjadi kewenangan pemerintah di luar urusan pemerintahan sebagaimana tersebut di atas, pemerintah dapat :

a. Menyelenggarakan sendiri sebagian urusan pemerintahan

b. Melimpahkan sebagian urusan pemerintahan kepada Gubernur selaku wakil pemerintah (dekonsentrasi); atau menugaskan sebagian urusan kepada pemerintahan daerah dan/atau pemerintahan desa berdasarkan asas tugas pembantuan. (Edie Toet Hendratno : 2009 : 180).

Apabila kita melihat pembagian urusan pemerintahan di Indonesia, pada hakikatnya dibagi dalam tiga kategori yakni urusan pemerintahan yang dikelola oleh pemerintah pusat (pemerintah); urusan pemerintah yang dilaksanakan oleh pemerintah daerah provinsi; urusan pemerintah yang dilaksanakan oleh pemerintah kabupaten/ kota. (H. Siswanto Sunarno : 2004 : 34-36).

Dalam peraturan perundang-undangan kita, yang mengatur tentang Pemerintahan Daerah adalah Undang-Undang Nomor 32 Tahun 2004 dan selaku peraturan pelaksananya adalah Peraturan Pemerintah Nomor 38 Tahun 2007 tentang Tentang Kewenangan Pemerintah dan Kewenangan
Propinsi sebagai Daerah Otonom. Undang-Undang Nomor 32 Tahun 2004 memberikan pelaksanaan prinsip otonomi yang seluas-luasnya kepada daerah, akan tetapi Undang-Undang ini belum secara eksplisit mengatur tentang pembagian kewenangan antara pemerintah pusat dan daerah bahkan tidak memberikan kewenangan sepenuhnya kepada daerah otonom dalam pelaksanaan pemerintahan di daerah.

Sehubungan dengan kewenangan, maka sesuai Pasal 10 ayat (1) Undang-Undang Nomor 32 Tahun 2004, ditegaskan bahwa "Pemerintahan daerah dalam menyelenggarakan urusan pemerintahan yang menjadi kewenangannya, kecuali urusan pemerintahan yang oleh undang-undang ini ditentukan menjadi urusan pemerintah". Lebih lanjut dalam ayat (2) bahwa "Dalam menyelenggarakan urusan pemerintahan yang menjadi kewenangan daerah sebagaimana dimaksud pada ayat (1), pemerintahan daerah menjalankan otonomi seluas-luasnya untuk mengatur dan mengurus sendiri urusan pemerintahan berdasarkan asas otonomi dan tugas pembantuan". Ayat (3) ditegaskan bahwa "Urusan pemerintahan yang menjadi urusan pemerintah sebagaimana dimaksud pada ayat (1) meliputi :

a. Politik luar negeri

b. Pertahanan

c. Keamanan

d. Yustisi

e. Moneter dan fiskal nasional

f. Agama

Berkaitan dengan pemanfaatan sumber daya alam, Pasal 17 ayat (1) Undang-Undang Nomor 32 Tahun 2004 menegaskan bahwa "Hubungan dalam bidang pemanfaatan sumber daya alam dan sumber daya lainnya antara pemerintah dan pemerintah daerah sebagaimana dimaksud dalam Pasal 2 ayat (4) dan ayat (5) meliputi

a. Kewenangan, tanggung jawab, pemanfaatan, pemeliharaan, pengendalian dampak, budi daya, dan pelestarian; 
b. Bagi hasil atas pemanfaatan sumber daya alam dan sumber daya alam lainnya; dan

c. Penyerasian lingkungan dan tata ruang serta rehabilitasi lahan.

Lebih lanjut pasal 17 ayat (2) menegaskan bahwa "Hubungan dalam bidang pemanfaatan sumber daya alam dan sumber daya alam lainnya antar pemerintahan daerah sebagaimana dimaksud dalam Pasal 2 ayat (4) dan ayat (5) meliputi

a. Pelaksanaan pemanfaatan sumber daya alam dan sumber daya lainnya yang menjadi kewenangan daerah;

b. Kerja sama dan bagi hasil atas pemanfaatan sumber daya alam dan sumber daya lainnya antarpemerintahan daerah; dan

c. Pengelolaan perizinan bersama dalam pemanfaatan sumber daya alam dan sumber daya lainnya.

Mengacu dari pemikiran bahwa pemerintah daerah memiliki kewenangan dalam pemanfaatan sumber daya alam dan sumber daya lainnya, maka membawa implikasi bagi pengelolaan lingkungan hidup yaitu bahwa pemerintah daerah memiliki kewenangan dan tanggung jawab penuh untuk mengeluarkan izin bagi setiap kegiatan dalam wilayah daerahnya.Untuk mencegah timbulnya kerusakan lingkungan hidup, diupayakan pelestarian lingkungan, sebagai penjabaran dari kebijakan tersebut, pemerintah menuangkannya dalam instrumen izin yang digunakan oleh penguasa. Undang-Undang nomor 32 tahun 2009 tentang Perlindungan dan Pengelolaan Lingkungan Hidup, dalam hal perizinan didapati bahwa sebagian urusan tersebut menjadi kewenangan pemerintah maupun pemerintah daerah.

Mengenai pembagian kewenangan antara pemerintah dan pemerintah daerah diatur dalam Peraturan Pemerintah Nomor 38 Tahun 2007 tentang Pembagian Urusan Pemerintahan Antara Pemerintah, Pemerintahan daerah Provinsi, Dan Pemerintah Kabupaten/Kota pada bagian lampiran bidang lingkungan hidup terdapat
2 sub bidang dan 19 sub-sub bidang yang membagi urusan yang menjadi kewenangan pemerintah, pemerintah provinsi, dan pemerintah kabupaten/kota.

Dalam Peraturan Pemerintah Nomor 38 Tahun 2007, termaktub bahwa urusan yang menjadi kewenangan daerah terdiri atas urusan wajib dan urusan pilihan. Urusan pemerintahan wajib diselenggarakan oleh pemerintah daerah yang terkait dengan pelayanan dasar (basic services), antara lain pendidikan dasar; kesehatan; lingkungan hidup; pekerjaan umum; penataan ruang; perencanaan pembangunan; perumahan; kepemudaan dan olahraga; penanaman modal; koperasi dan usaha kecil dan menengah; kependudukan dan catatan sipil; ketenagakerjaan; ketahanan pangan; pemberdayaan perempuan dan perlindungan anak; keluarga berencana dan keluarga sejahtera; perhubungan; komunikasi dan informatika; pertanahan; kesatuan bangsa dan politik dalam negeri; otonomi daerah pemerintahan umum, administrasi keuangan daerah, perangkat daerah, kepegawaian, dan persandian; pemberdayan masyarakat dan desa; sosial; kebudayaan; statistik; kearsipan; dan perpustakaan.

Urusan pemerintahan yang bersifat pilihan adalah urusan pemerintahan yang secara nyata ada dan berpotensi untuk meningkatkan kesejahteraan masyarakat sesuai dengan kondisi, kekhasan, dan potensi unggulan daerah yang bersangkutan (core competence). Urusan pilihan tersebut meliputi kelautan dan perikanan; pertanian; kehutanan; energi dan sumber daya mineral; pariwisata; industri; perdagangan; dan ketransmigrasian.

Urusan pemerintahan di luar urusan wajib dan urusan pilihan yang diselenggarakan oleh pemerintah daerah, sepanjang menjadi kewenangan daerah yang bersangkutan tetap harus diselenggarakan oleh pemerintah daerah yang bersangkutan. Mengingat terbatasnya sumber daya dan sumber dana yang dimiliki oleh daerah, maka prioritas penyelenggaraan urusan pemerintahan difokuskan pada urusan wajib 
dan urusan pilihan yang benar-benar mengarah pada penciptaan kesejahteraan masyarakat disesuaikan dengan kondisi, potensi, dan kekhasan daerah yang bersangkutan.

Lingkungan hidup merupakan bagian dari urusan wajib, yang mana dalam lampiran PP Nomor 38 Tahun 2007 huruf H tentang Pembagian Urusan Pemerintahan Bidang Lingkungan Hidup, terdapat 2 sub bidang dan 19 sub-sub bidang yang diatur. Dua sub-sub bidang tersebut antara lain pengendalian dampak lingkungan, yang terdiri dari 18 sub-sub bidang; dan konservasi sumber daya alam (SDA), yang terdiri dari 1 sub-sub bidang. Sub-sub bidang yang termasuk dalam pengendalian dampak lingkungan antara lain :

1. Pengelolaan Limbah Bahan Berbahaya dan Beracun (B3);

2. Analisis Mengenai Dampak Lingkungan (AMDAL);

3. Pengelolaan Kualitas Air dan Pengendalian Pencemaran Air;

4. Pengelolaan Kualitas Udara dan Pengendalian Pencemaran Udara;

5. Pengendalian Pencemaran dan/atau Kerusakan Pesisir dan Laut;

6. Pengendalian Pencemaran dan/atau Kerusakan Tanah Akibat Kebakaran Hutan dan/atau Lahan;

7. Pengendalian Pencemaran dan/atau Kerusakan Tanah Untuk Kegiatan;

8. Penanggulangan Pencemaran dan Kerusakan Lingkungan Akibat Bencana;

9. Standar Nasional Indonesia (SNI) dan Standar Kompetensi Personil Bidang Lingkungan Hidup;

10. Pengembangan Perangkat Ekonomi Lingkungan;

11. Penerapan Sistem Manajemen Lingkungan, Ekolabel, Produksi Bersih, dan Teknologi Berwawasan Lingkungan;

12. Pendidikan dan Pelatihan (Diklat);

13. Pelayanan Bidang Lingkungan Hidup;
14. Pembinaan dan Pengawasan atas Penyelenggaraan Otonomi Daerah Bidang Lingkungan Hidup;

15. Penegakan Hukum Lingkungan;

16. Perjanjian Internasional di Bidang Pengendalian Dampak Lingkungan;

17. Perubahan Iklim dan Perlindungan Atmosfir; dan

18. Laboratorium Lingkungan.

Adapun sub-sub bidang dalam konservasi sumber daya alam (SDA) yaitu keanekaragaman hayati.

Perizinan dalam lingkungan hidup berdasarkan Undang-Undang Nomor 32 Tahun 2009 tentang Perlindungan dan Pengelolaan Lingkungan Hidup, baik itu berupa izin lingkungan, izin usaha, maupun izin kegiatan dalam cara memperoleh wewenangnya merupakan delegasi dan pengaturan wewenang tersebut dimiliki oleh Menteri, Gubernur, Bupati/Walikota. Hal ini berarti pula bahwa pemerintah daerah sebagai penerima delegasi berwenang memberikan izin pengelolaan lingkungan hidup dan bertanggung jawab terhadap tindakannya.

Dalam penyelenggaraan pemerintahan, yang menjadi perhatian penting adalah pelayanan publik. Salah satu bentuk pelayan publik yang dilakukan oleh pemerintah adalah pelayanan perizinan. Sebagai bentuk kegiatan publik, maka kegiatan perizinan harus dilaksanakan dengan didasarkan pada asas-asas umum pemerintahan yang baik sebagai norma perilaku bagi aparatur pemerintahan.Undang-Undang Nomor 25 Tahun 2009 Tentang Pelayanan Publik ditegaskan tentang asas-asas penyelenggaraan publik untuk dijadikan dasar penyelenggaraan publik sebagai berikut :

1. Asas kepentingan umum, yaitu pemberian pelayanan tidak boleh mengutamakan kepentingan pribadi dan/atau golongan;

2. Asas kepastian hukum, yaitu jaminan terwujudnya hak dan kewajiban dalam penyelenggaraan pelayanan;

3. Asas kesamaan hak, yaitu pemberian pelayanan tidak boleh membedakan 
suku, ras, agama, golongan, gender, dan status ekonomi;

4. Asas keseimbangan hak dan kewajiban, yaitu pemenuhan hak harus sebanding dengan kewajiban yang harus dilaksanakan baik oleh pemberi maupun penerima pelayanan;

5. Asas keprofesionalan, yaitu pelaksana pelayanan harus memiliki kompetensi yang sesuai dengan bidang tugas;

6. Asas partisipatif, yaitu peningkatan peran serta masyarakat dalam penyelenggaraan pelayanan dengan memperhatikan aspirasi, kebutuhan, dan harapan masyarakat;

7. Asas persamaan perlakuan/tidak diskriminatif, yaitu setiap warga negara berhak memperoleh pelayanan yang adil;

8. Asas keterbukaan, yaitu setiap penerima pelayanan dapat dengan mudah mengakses dan memperoleh informasi mengenai pelayanan yang diinginkan;

9. Asas akuntabilitas, yaitu proses penyelenggaraan pelayanan harus dapat dipertanggungjawabkan sesuai dengan ketentuan peraturan perundang-undangan;

10. Asas fasilitas dan perlakuan khusus bagi kelompok rentan, yaitu pemberian kemudahan terhadap kelompok rentan sehingga tercipta keadilan dalam pelayanan;

11. Asas ketepatan waktu, yaitu penyelesaian setiap jenis pelayanan dilakukan tepat waktu sesuai dengan standar pelayanan; dan

12. Asas kecepatan, kemudahan, dan keterjangkauan, yaitu setiap jenis pelayanan dilakukan secara cepat, mudah dan terjangkau.

Pelayanan perizinan yang dilakukan oleh pemerintah merupakan salah satu bentuk pelayanan publik. Sebagai bentuk kegiatan publik, maka kegiatan perizinan harus dilaksanakan dengan didasarkan pada asas-asas umum pemerintahan yang baik sebagai norma perilaku bagi aparatur pemerintahan. Perizinan yang dilakukan oleh Pemerintah Daerah perlu dikembangkan dalam bentuk Pelayanan Terpadu Satu Pintu. Menyangkut Pelayan Terpadu Satu Pintu, pemerintah melalui Departemen Dalam Negeri telah meluncurkan kebijakan yang tertuang dalam Peraturan Menteri Dalam Negeri Nomor 24 Tahun 2006 tentang Penyelenggaraan Pelayanan Terpadu Satu Pintu. Peraturan ini pada intinya meminta pemerintah daerah untuk melakukan kegiatan seperti berikut ini :

a. Penyederhanaan sistem dan prosedur perizinan usaha

b. Pembentukan lembaga pelayaran perizinan terpadu satu pintu di daerah

c. Pemangkasan waku dan biaya perizinan

d. Perbaikan sistem pelayanan

e. Perbaikan sistem informasi

f. Pelaksanaan monitoring dan evaluasi proses penyelenggaraan perizinan.

Adapaun alasan pemerintah melaksanakan penyelenggaraan pelayanan terpadu satu pintu adalah :

a. Perizinan merupakan pelayanan pemerintah yang tidak dapat digantikan oleh pihak swasta

b. Perizinan adalah entry point kegiatan usaha

c. Perizinan adalah persyaratan bagi akses terhadap modal

d. Perizinan adalah fungsi awal untuk melakukan control dalam pembinaan

e. Perizinan menghasilkan pendapatan asli daerah dan dapat menambah objek pajak

f. Pelayanan perizinan merupakan salah satu cermin kualitas pelayanan pemerintah kepada masyarakatnya.

Pelayanan terpadu satu pintu adalah kegiatan penyelenggaraan perizinan dan non perizinan, yang proses pengelolaannya dilakukan secara terpadu dalam satu tempat, dengan menganut prinsip kesederhanaan, transparansi, akuntabilitas, dan menjamin kepastian biaya, waktu, serta kejelasan prosedur. Dengan konsep itu dalam mengurus perizinan, pemohon cukup hanya datang ke satu tempat dan hanya bertemu dengan petugas front office sehingga dapat 
meminimalisasi interaksi antara pemohon dengan petugas perizinan dan menghindari pungutan tidak resmi.

Pemberian perizinan dalam pengelolaan sumber daya alam harus dilaksanakan dalam sistem dan prinsip perizinan yang tersendiri.Dalam hal ini, sistem perizinan harus didasarkan pada konsep pelayanan terpadu satu pintu dengan didasarkan pada prinsip Good Licensing Governance on Based Natural Resources (Penyelenggaraan Perizinan Yang Baik Dalam Pengelolaan Sumber Daya Alam).

Prinsip Good Licensing Governance on Based Natural Resources ini terlaksana dengan didasarkan pada beberapa prinsip hukum, antara lain sebagai berikut (S.E.M. Nirahua : 2010 : 264) :

1. Prinsip keberlanjutan

Prinsip ini menjadi landasan dalam penyelenggaraan perizinan pengelolaan sumber daya alam.Aparatur pemerintahan harus memperhatikan prinsip keberlanjutan agar tidak sebebas-bebasnya memberikan izin tanpa adanya batasan.

2. Prinsip eksploitasi terbatas

Prinsip ini memiliki keterkaitan dengan prinsip keberlanjutan, dimana pengelolaan sumber daya alam melalui tahap eksploitasi harus bersifat terbatas untuk memberikan keberlanjutan sumber daya alam itu seniri.

3. Prinsip akuntabilitas

Akuntabilitas merupakan ukuran atau standar yang menunjukan seberapa besar tingkat kesesuaian penyelenggaraan perizinan sebagai kebijakan publik sesuai dengan peraturan perundang-undangan dan dapat dipertanggungjawabkan setiap kebijakan yang diambil kepada publik.Prinsip ini dikembangkan sebagai bentuk pertanggungjawaban publik atas kepercayaan yang diberikan kepada aparatur pemerintahan dalam pengelolaan sumber daya alam.

4. Prinsip partisipasi

Prinsip ini digunakan dengan pertimbangan bahwa penyelenggaraan pemerintahan oleh aparatur pemerintah dalm pemberian perizinan harus memberikan ruang partisipasi bagi pihak ketiga maupun masyarakat dalam proses perizinan. Dalam kaitan dengan prinsip partisipasi, proses perizinan dilakukan dengan melibatkan pihak ketiga yang terlibat dalam pengelolaan sumber daya alam melalui permohonan perizinan agar diperoleh kesesuaian antara permohonan yang diajukan dengan kenyataan dalam proses pengelolaan sumber daya alam. Di samping itu, masyarakat pun harus dilibatkan dalam proses pengambilan keputusan melalui penyelenggaraan perizinan, karena pengelolaan sumber daya alam di wilayah memiliki keterkaitan dengan masyarakat sebagai stakeholder dalam memberikan pelayan publik.

5. Prinsip transparansi

Prinsip ini merujuk pada keterbukaan informasi dan kejelasan bagi masyarakat berkaitan dengan penyelenggaraan perizinan pengelolaan sumber daya alam.Bagi masyarakat prinsip ini merupakan alat kontrol yang dilakukan oleh aparatur pemerintahan dalam penyelenggaraan perizinan pengelolaan sumber daya alam.

6. Prinsip pelayanan terpadu

Prinsip ini merupakan bentuk pelayanan publik yang memberikan kemudahan baik pelayanan administrasi maupun pembiayaan dalam perizinan serta adanya pelayanan yang efektif.

Pelayanan Terpadu Satu Pintu di tingkat pusat dilakukan oleh lembaga yang berwenang di bidang penanaman modal yang mendapat pendelegasian dari lembaga yang memiliki kewenangan perizinan dan nonperizinan di tingkat pusat, propinsi atau kabupaten/kota.Lembaga yang dimaksud disini adalah Badan Koordinasi Penanaman Modal (BKPM) atau Badan Koordinasi Penanaman Modal Daerah (BKPMD). Dengan menjalankan sistem Pelayanan Terpadu Satu Pintu lewat Badan Koordinasi Penanaman Modal Daerah maka diharapkan 
segala perizinan dapat menjadi mudah begitu pun dengan izin pengelolaan lingkungan hidup.

\section{PE N U T U P}

Berdasarkan penulisan diatas, dapat disimpulkan bahwa wewenang pemberian izin pengelolaan lingkungan hidup oleh pemerintah daerah, belum maksimal dalam implementasinya oleh karena Undang-Undang Nomor 32 Tahun 2009 tentang Perlindungan dan Pengelolaan Lingkungan Hidup dan peraturan pelaksananya belum lengkap terkait dengan pembagian kewenangan yang dimiliki oleh penyelenggara pemerintahan yang berwenang, baik di pusat maupun daerah.

\section{DAFTAR PUSTAKA}

Edie Toet Hendratno, 2009, Negara Kesatuan, Desentralisasi dan Federalisme, Graha Ilmu, Yogyakarta.

H. Siswanto Sunarno, 2009, Hukum Pemerintahan Daerah di Indonesia, Sinar Grafika, Jakarta.

Philipus M Hadjon, 1993, Pengantar Hukum Perizinan, Yuridika, Surabaya.

Prajudi Atmosudirdjo, 1994, Hukum Administrasi Negara, Ghalia Indonesia, Jakarta.

Ridwan HR, 2006, Hukum Administrasi Negara, PT. RajaGrafindo Persada, Jakarta.

Supriadi, 2006, Hukum Lingkungan Di Indonesia, Sebuah Pengantar,Sinar Grafika, Jakarta.

Alvi Syahrin, Perizinan Lingkungan Dan Aspek Hukum Pidana Lingkungan. Berdasarkan Undang-Undang Nomor 32 Tahun 2009 Tentang Perlindungan
Dan Pengelolaan Lingkungan Hidup (Disampaikan Pada Acara: Focus Group Discussion: "Peraturan Lingkungan Hidup dalam Perspektif Perizinan bagi Perusahaan" ) DPP APINDO Sumatera Utara, tanggal 22 Juli 2010, Medan.

S.E.M. Nirahua, 2010, Problematika Yuridis Kewenangan Pemerintah Daerah di Bidang Perizinan Dalam Pengelolaan Sumber Daya Alam Wilayah Laut (Disertasi).

Undang-Undang Nomor 32 Tahun 2009

Tentang Perlindungan dan

Pengelolaan Lingkungan Hidup.

Undang-Undang Nomor 32 Tahun 2004

Tentang Pemerintahan Daerah.

Undang-Undang Nomor 25 Tahun 2009

Tentang Pelayanan Publik

Peraturan Pemerintah Republik Indonesia

Nomor 27 Tahun 2012 Tentang Izin

Lingkungan

Peraturan Menteri Dalam Negeri Nomor 24

Tahun 2006 tentang Penyelenggaraan

Pelayanan Terpadu Satu Pintu 